\title{
Ocena skutków regulacji rządowego projektu ustawy o uregulowaniu niektórych spraw w związku z wystąpieniem Zjednoczonego Królestwa Wielkiej Brytanii i Irlandii Północnej z Unii Europejskiej i Europejskiej Wspólnoty Energii Atomowej na podstawie umowy, o której mowa w art. 50 ust. 2 Traktatu o Unii Europejskiej ${ }^{1}$
}

Przepisy projektowanej ustawy znajdą zastosowanie wyłącznie w przypadku, gdy wystąpienie Zjednoczonego Królestwa z Unii Europejskiej nastąpi na podstawie umowy, o której mowa w art. 50 ust. 2 TUE. Do dnia sporządzenia opinii w Zjednoczonym Królestwie nie zakończyły się wewnętrzne procedury mające na celu zatwierdzenie umowy. Obecnie nie wiadomo jeszcze, czy wystąpienie Zjednoczonego Królestwa z UE nastąpi na podstawie umowy, o której mowa w art. 50 ust. 2 TUE, czy bez takiej umowy.

Słowa kluczowe: projekt ustawy, brexit, Unia Europejska, Wielka Brytania

Impact assessment of governmental Bill on Regulation of Certain Matters in Relation to the withdrawal of the United Kingdom of Great Britain and Northern Ireland from the European Union and the European Atomic Energy Community on the Basis of an Agreement Referred to in Article 50(2) of the Treaty on European Union: The provisions of the bill will be applied only, if the United Kingdom leaves the European Union on the basis of the agreement referred to in Article 50(2) TEU. Until the day of completion of the author's opinion, internal procedures concerning the approval of the Agreement have not been completed in the United Kingdom. At present, it is not yet clear, whether the United Kingdom would leave the EU on the basis of an agreement as referred to in Article 50(2) TEU or without such agreement.

Keywords: bill, brexit, European Union, Great Britain

Ekspert ds. legislacji BAS • bartosz.pawlowski@sejm.gov.pl • https://orcid.org/0000-0002-8764-6474

\section{Przedmiot opinii}

Przedmiotem opinii jest rządowy projekt ustawy o uregulowaniu niektórych spraw w związku z wystąpieniem Zjednoczonego Królestwa Wielkiej Brytanii

1 Ocena skutków regulacji rządowego projektu ustawy o uregulowaniu niektórych spraw w związku z wystąpieniem Zjednoczonego Królestwa Wielkiej Brytanii i Irlandii Północnej z Unii Europejskiej i Europejskiej Wspólnoty Energii Atomowej na podstawie umowy, o której mowa w art. 50 ust. 2 Traktatu o Unii Europejskiej sporządzona 17 maja 2019 r. na zlecenie zastępcy Szefa Kancelarii Sejmu; BAS-WAPEiM 966/19. 
i Irlandii Północnej z Unii Europejskiej i Europejskiej Wspólnoty Energii Atomowej na podstawie umowy, o której mowa w art. 50 ust. 2 Traktatu o Unii Europejskiej (dalej: TUE). Należy zaznaczyć, że projekt ustawy odwołuje się do konkretnej umowy - chodzi o umowę o wystąpieniu Zjednoczonego Królestwa Wielkiej Brytanii i Irlandii Północnej z Unii Europejskiej i Europejskiej Wspólnoty Energii Atomowej (Dz.Urz. UE C 66 A/I z 19 lutego 2019 r., s. 1; dalej: umowa).

\section{Geneza, przedmiot i obowiązywanie umowy}

Z uwagi na to, że projekt ustawy jest bezpośrednio związany z wystąpieniem Zjednoczonego Królestwa z Unii Europejskiej, należy odnieść się do prawnych regulacji określających ramy tej procedury oraz dotychczasowego jej przebiegu.

Zgodnie $z$ art. 50 ust. 1 TUE każde państwo członkowskie może, zgodnie ze swoimi wymogami konstytucyjnymi, podjąć decyzję o wystąpieniu z Unii. Państwo członkowskie, które podjęło decyzję o wystąpieniu, notyfikuje swój zamiar Radzie Europejskiej. Zgodnie z wytycznymi Rady Europejskiej Unia prowadzi negocjacje i zawiera $z$ tym państwem umowę określającą warunki jego wystąpienia, uwzględniając ramy jego przyszłych stosunków z Unią. Umowę tę negocjuje się zgodnie z art. 218 ust. 3 Traktatu o funkcjonowaniu Unii Europejskiej (dalej: TFUE). Jest ona zawierana w imieniu Unii przez Radę, stanowiącą większością kwalifikowaną po uzyskaniu zgody Parlamentu Europejskiego (art. 50 ust. 2 TUE).

W dniu 29 marca 2017 r. Rada Europejska otrzymała od Wielkiej Brytanii notyfikację informującą o zamiarze wystąpienia z Unii Europejskiej. Na posiedzeniu 29 kwietnia 2017 r. Rada Europejska przyjęła wytyczne opracowane w następstwie notyfikacji złożonej przez Wielką Brytanię na mocy art. 50 TUE². Przedmiotem tych wytycznych było zdefiniowanie ram negocjacji prowadzonych na podstawie art. 50 TUE oraz określenie ogólnych stanowisk i zasad, którymi Unia kieruje się w toku negocjacji.

W dniu 22 maja 2017 r. Rada przyjęła decyzję upoważniającą do rozpoczęcia negocjacji z Wielką Brytanią i formalnie wyznaczyła Komisję na negocjatora UE³. W dniu 29 stycznia 2018 r. Rada przyjęła decyzję uzupełniającą decyzję z 22 maja 2017 r. ${ }^{4}$. Zgodnie z art. 1 tego aktu Komisja prowadziła, w imieniu Unii, negocjacje w sprawie umowy z Wielką Brytanią, określającej warunki jej wystąpienia

2 Https://www.consilium.europa.eu/media/21753/29-euco-art50-guidelines-pl.pdf.

3 Decyzja Rady (UE, Euratom) XT 21016/17 z 22 maja 2017 r. upoważniająca do rozpoczęcia negocjacji ze Zjednoczonym Królestwem Wielkiej Brytanii i Irlandii Północnej w sprawie umowy określającej warunki jego wystąpienia z Unii Europejskiej.

4 Decyzja Rady (UE, Euratom) XT 21004/18 z 29 stycznia 2018 r. uzupełniająca decyzję Rady z 22 maja 2017 r. upoważniającą do rozpoczęcia negocjacji ze Zjednoczonym Królestwem Wielkiej Brytanii i Irlandii Północnej w sprawie umowy określającej warunki jego wystąpienia z Unii Europejskiej. 
z Unii Europejskiej i Europejskiej Wspólnoty Energii Atomowej, uwzględniając ramy jej przyszłych stosunków z Unią, zgodnie z wytycznymi przyjętymi przez Radę Europejską oraz z wytycznymi negocjacyjnymi określonymi w załączniku do decyzji Rady z 22 maja 2017 r., uzupełnionymi wytycznymi negocjacyjnymi określonymi w załączniku do decyzji z 29 stycznia $2018 \mathrm{r}$.

W dniu 25 listopada 2018 r. Rada Europejska zatwierdziła umowę. W dniu 11 stycznia 2019 r. Rada podjęła decyzję w sprawie podpisania umowy ${ }^{5}$ (dalej: decyzja 2019/274).

Zgodnie $\mathrm{z}$ art. 1 umowy określa ona warunki wystąpienia Zjednoczonego Królestwa z Unii Europejskiej i Europejskiej Wspólnoty Energii Atomowej (dalej: Euratom). W preambule umowy podkreślono, że celem tego dokumentu jest zapewnienie uporządkowanego wystąpienia Zjednoczonego Królestwa z Unii i Euratomu oraz że strony umowy są zdecydowane zapewnić uporządkowane wystąpienie poprzez różnorakie dotyczące go postanowienia mające na celu zapobiegnięcie zakłóceniom i zapewnienie pewności prawa obywatelom i podmiotom gospodarczym, jak również organom sądowym i administracyjnym w Unii i Zjednoczonym Królestwie.

Zgodnie z art. 185 umowy miała ona wejść w życie 30 marca 2019 r., natomiast w przypadku gdyby przed tą datą depozytariusz umowy (Sekretarz Generalny Rady) nie otrzymał pisemnego powiadomienia o zakończeniu niezbędnych procedur wewnętrznych przez Unię i przez Zjednoczone Królestwo, umowa miała nie wejść w życie.

Decyzją (UE) 2019/47616 Rada Europejska w porozumieniu ze Zjednoczonym Królestwem postanowiła o przedłużeniu okresu przewidzianego w art. 50 ust. 3 TUE do 22 maja 2019 r. w przypadku, gdy Izba Gmin zatwierdzi umowę o wystąpieniu do 29 marca 2019 r. albo, jeżeli tak się nie stanie, do 12 kwietnia 2019 r. Izba Gmin nie zatwierdziła umowy o wystąpieniu do 29 marca 2019 r.

W dniu 5 kwietnia 2019 r. Zjednoczone Królestwo złożyło w Radzie Europejskiej kolejny wniosek w sprawie przedłużenia okresu przewidzianego w art. 50 ust. 3 TUE. W dniu 11 kwietnia 2019 r. decyzją (UE) 2019/584 Rada Europejska, w porozumieniu ze Zjednoczonym Królestwem, podjęła decyzję o przedłużeniu tego okresu do 31 października 2019 r.7. Również w dniu 11 kwietnia 2019 r.

5 Decyzja Rady (UE) 2019/274 z 11 stycznia 2019 r. w sprawie podpisania, w imieniu Unii Europejskiej i Europejskiej Wspólnoty Energii Atomowej, umowy o wystąpieniu Zjednoczonego Królestwa Wielkiej Brytanii i Irlandii Północnej z Unii Europejskiej i Europejskiej Wspólnoty Energii Atomowej, Dz.Urz. UE L 47 I z 19 lutego 2019 r., s. 1.

6 Decyzja Rady Europejskiej (UE) 2019/476 przyjęta w porozumieniu ze Zjednoczonym Królestwem z 22 marca 2019 r. przedłużająca okres, o którym mowa w art. 50 ust. 3 TUE, Dz.Urz. UE L 80 I z 22 marca 2019 r., s. 1.

7 Decyzja Rady Europejskiej (UE) 2019/584 przyjęta w porozumieniu ze Zjednoczonym Królestwem z 11 kwietnia 2019 r. przedłużająca okres, o którym mowa w art. 50 ust. 3 TUE, Dz.Urz. UE L 101 z 11 kwietnia 2019 r., s. 1. 
w porozumieniu ze Zjednoczonym Królestwem została zmieniona umowa w zakresie dotyczącym terminu jej wejścia w życie - w art. 185 akapit pierwszy otrzymał brzmienie: Niniejsza Umowa wchodzi w życie $w$ jednej $z$ następujących dat, w zależności od tego, która z nich przypadnie wcześniej: (a) dzień następujący po upływie okresu przewidzianego w art. 50 ust. 3 TUE, przedłużonego przez Radę Europejska w porozumieniu ze Zjednoczonym Królestwem, pod warunkiem że przed ta data depozytariusz niniejszej Umowy otrzyma pisemne powiadomienia od Unii i Zjednoczonego Królestwa o zakończeniu niezbędnych procedur wewnętrznych; (b) pierwszy dzień miesiaca następującego po otrzymaniu przez depozytariusza niniejszej Umowy ostatniego z pisemnych powiadomień, o których mowa $w$ lit. a). W przypadku gdy przed uplywem okresu przewidzianego w art. 50 ust. 3 TUE, przedłużonego przez Radę Europejska w porozumieniu ze Zjednoczonym Królestwem, depozytariusz niniejszej Umowy nie otrzyma pisemnych powiadomień, o których mowa $w$ lit. a), niniejsza Umowa nie wchodzi $w \dot{z} y c i e$.

Zgodnie $\mathrm{z}$ art. 126 umowy ustanowiony został okres przejściowy lub okres wdrażania, który rozpocznie się z dniem wejścia w życie umowy i skończy się 31 grudnia 2020 r. Wspólny Komitet ${ }^{8}$ może jednak, przed dniem 1 lipca 2020 r., przyjąć jedną decyzję przedłużającą okres przejściowy o maksymalnie rok lub dwa lata (art. 132 ust. 1 umowy).

Zakres okresu przejściowego wyznacza art. 127 umowy. Zgodnie z tym przepisem, o ile umowa nie stanowi inaczej, w okresie przejściowym prawo Unii ma zastosowanie do Zjednoczonego Królestwa i na jego terytorium. Równocześnie przepis ten określa wyjątki. I tak, do Zjednoczonego Królestwa nie będą miały zastosowania w okresie przejściowym:

- postanowienia traktatów i aktów, które zgodnie z protokołem (nr 15) w sprawie niektórych postanowień dotyczących Zjednoczonego Królestwa Wielkiej Brytanii i Irlandii Północnej, protokołem (nr 19) w sprawie dorobku Schengen włączonego w ramy Unii Europejskiej oraz protokołem (nr 21) w sprawie stanowiska Zjednoczonego Królestwa i Irlandii w odniesieniu do przestrzeni wolności, bezpieczeństwa i sprawiedliwości lub zgodnie z postanowieniami traktatów dotyczącymi wzmocnionej współpracy nie były wiążące dla Zjednoczonego Królestwa ani na jego terytorium przed datą wejścia w życie niniejszej umowy, jak również akty zmieniające takie akty,

- art. 11 ust. 4 TUE, art. 20 ust. 2 lit. b, art. 22 i art. 24 akapit pierwszy TFUE, art. 39 i 40 Karty praw podstawowych Unii Europejskiej oraz akty przyjęte na podstawie tych postanowień.

W przypadku osiągnięcia przez Unię i Zjednoczone Królestwo porozumienia w sprawie umowy dotyczącej ich przyszłych stosunków w dziedzinie wspólnej polityki zagranicznej i bezpieczeństwa oraz wspólnej polityki bezpieczeństwa

8 Skład i zadania Wspólnego Komitetu określa art. 164 umowy. 
i obrony, której stosowanie rozpocznie się w trakcie okresu przejściowego, tytuł $\mathrm{V}$ rozdział 2 TUE oraz akty przyjęte na podstawie tych postanowień przestają mieć zastosowanie do Zjednoczonego Królestwa od daty rozpoczęcia stosowania takiej umowy (art. 127 ust. 2 umowy).

W okresie przejściowym prawo UE mające zastosowanie do Zjednoczonego Królestwa wywołuje takie same skutki prawne w odniesieniu do Zjednoczonego Królestwa i w Zjednoczonym Królestwie, jakie wywołuje w Unii i w jej państwach członkowskich, oraz jest stosowane zgodnie $\mathrm{z}$ tymi samymi metodami i ogólnymi zasadami, jak te mające zastosowanie w UE (art. 127 ust. 3 umowy). Zjednoczone Królestwo nie będzie uczestniczyć jednak we wzmocnionej współpracy, w odniesieniu do której decyzję upoważniającą przyjęto po dacie wejścia w życie umowy lub w ramach której nie przyjęto żadnych aktów przed datą wejścia w życie umowy

W okresie przejściowym art. 5 protokołu (nr 19) w sprawie dorobku Schengen włączonego w ramy Unii Europejskiej oraz art. 4a protokołu (nr 21) w sprawie stanowiska Zjednoczonego Królestwa i Irlandii w odniesieniu do przestrzeni wolności, bezpieczeństwa i sprawiedliwości będzie stosować się odpowiednio do środków, które zmieniają lub zastępują obowiązujące środki przyjęte zgodnie z częścią trzecią tytuł V TFUE lub też opierają się na nich, którymi Zjednoczone Królestwo jest związane przed wejściem w życie niniejszej umowy. Zjednoczone Królestwo nie ma jednak prawa zgłosić zamiaru udziału w stosowaniu nowych środków zgodnie z częścią trzecią tytuł V TFUE, poza środkami, o których mowa w art. 4a protokołu (nr 21).

Umowa stanowi, że - z zastrzeżeniem jej odmiennych postanowień - w okresie przejściowym wszelkie odniesienia do państw członkowskich w prawie Unii mającym zastosowanie do Zjednoczonego Królestwa, w tym wdrażanym i stosowanym przez państwa członkowskie, rozumie się jako odniesienia obejmujące również Zjednoczone Królestwo. Wyjątki od tej zasady określono w art. 137 ust. 7 umowy: - na użytek art. 42 ust. 6 i art. 46 TUE oraz protokołu (nr 10) w sprawie stałej współpracy strukturalnej ustanowionej na mocy artykułu 42 TUE, wszelkie odniesienia do państw członkowskich rozumie się jako odniesienia nieobejmujące Zjednoczonego Królestwa. Nie wyklucza to możliwości zaproszenia Zjednoczonego Królestwa, w wyjątkowych sytuacjach, do udziału jako państwo trzecie w pojedynczych projektach na warunkach określonych w decyzji Rady (WPZiB) 2017/2315 lub w innych formach współpracy w zakresie i na warunkach określonych w przyszłych aktach Unii przyjętych na podstawie art. 42 ust. 6 i art. 46 TUE, - jeżeli akty Unii przewidują udział państw członkowskich, obywateli państw członkowskich lub też osób fizycznych lub prawnych mających miejsce zamieszkania lub siedzibę w państwie członkowskim w wymianie informacji, postępowaniu lub programie, których wdrażanie jest kontynuowane po zakończeniu okresu przejściowego lub które rozpoczynają się po tej dacie, oraz jeśli taki udział wiązałby się z dostępem do informacji szczególnie chronionych związanych 
z bezpieczeństwem, o których wiedzę mogą mieć jedynie państwa członkowskie, obywatele państw członkowskich lub osoby fizyczne lub prawne mające miejsce zamieszkania lub siedzibę w państwie członkowskim, w takich wyjątkowych okolicznościach odniesienia do państw członkowskich w takich aktach Unii rozumie się jako odniesienia nieobejmujące Zjednoczonego Królestwa,

- dla potrzeb zatrudniania urzędników i innych pracowników instytucji, organów i jednostek organizacyjnych Unii wszelkie odniesienia do państw członkowskich w art. 27 i art. 28 lit. a regulaminu pracowniczego i w art. 1 załącznika X do tego regulaminu oraz w art. 12, 82 i 128 warunków zatrudnienia innych pracowników Unii Europejskiej lub w odpowiednich przepisach innych uregulowań dotyczących pracowników mających zastosowanie do tych instytucji, organów i jednostek organizacyjnych rozumie się jako odniesienia nieobejmujące Zjednoczonego Królestwa.

Postanowienia umowy dotyczące okresu przejściowego dotyczą także rozwiązań instytucjonalnych (art. 128), szczególnych ustaleń dotyczących działań zewnętrznych Unii (art. 129) oraz szczególnych ustaleń dotyczących uprawnień do połowów (art. 130).

Do dnia sporządzenia niniejszej opinii w Zjednoczonym Królestwie nie zakończyły się wewnętrzne procedury mające na celu zatwierdzenie umowy. Wobec powyższego nie można jednoznacznie przewidzieć, czy i kiedy umowa wejdzie w życie.

\section{Celowość wprowadzenia aktu}

Obecnie nie wiadomo jeszcze, czy wystąpienie Zjednoczonego Królestwa z Unii Europejskiej nastąpi na podstawie umowy, o której mowa w art. 50 ust. 2 TUE, czy bez takiej umowy. W dniu 15 marca 2019 r. uchwalona została ustawa o uregulowaniu niektórych spraw w związku z wystąpieniem Zjednoczonego Królestwa Wielkiej Brytanii i Irlandii Północnej z Unii Europejskiej i Europejskiej Wspólnoty Energii Atomowej bez zawarcia umowy, o której mowa w art. 50 ust. 2 Traktatu o Unii Europejskiej (Dz.U. poz. 622). Omawiany projekt ustawy dotyczy natomiast ewentualnego wystąpienia Zjednoczonego Królestwa z Unii Europejskiej na podstawie takiej umowy.

Umowa przewiduje w art. 126 następujący po dacie jej wejścia w życie okres przejściowy trwający do dnia 31 grudnia 2020 r., w którym Zjednoczone Królestwo w myśl prawa unijnego i w myśl krajowych przepisów wdrażających prawo Unii Europejskiej zasadniczo traktowane będzie dalej jak państwo członkowskie. Celem projektu ustawy - jak zaznaczono w uzasadnieniu - jest potwierdzenie tego skutku w okresie przejściowym w celu wyeliminowania ewentualnych wątpliwości w tym zakresie. Przepisy projektu odnoszą się zatem wyłącznie do okre- 
su przejściowego, o którym mowa w art. 126 umowy, czyli okresu rozpoczynającego się w dniu wystąpienia Zjednoczonego Królestwa z UE i kończącego się 31 grudnia 2020 r. W chwili obecnej nie jest pewne, czy relacje między państwami członkowskimi Unii a Zjednoczonym Królestwem będą, po upływie okresu przejściowego, regulowane umową o wystąpieniu, czy też umową (umowami) o przyszłych relacjach, o których mowa w art. 184 umowy. Z tego względu nie jest możliwe uregulowanie tej kwestii na obecnym etapie.

Zgodnie $\mathrm{z}$ projektem odniesienia w prawie polskim dotyczące praw i obowiązków związanych z członkostwem w Unii Europejskiej lub w Euratomie należy w trakcie okresu przejściowego rozumieć tak, że obejmują one także Zjednoczone Królestwo, o ile nie zachodzi żadne z odstępstw wymienionych w umowie lub projekcie. Zasada ta nie będzie zatem miała zastosowania do przepisów prawa polskiego, które stanowią wdrożenie odstępstw wymienionych w art. 127 ust. 1, 4, 5 i 7 umowy o wystąpieniu.

Warto zwrócić uwagę, że - jak wskazano w uzasadnieniu projektu ustawy ustawa może stanowić podstawę stosowania w okresie przejściowym europejskiego nakazu aresztowania wystawionego w Zjednoczonym Królestwie. Stosownie do art. 55 ust. 1 Konstytucji ekstradycja obywatela polskiego jest, co do zasady, zakazana. Zgodnie jednak z art. 55 ust. 2 Konstytucji; ekstradycja obywatela polskiego może być dokonana na wniosek innego państwa [...], jeżeli możliwość taka wynika z ratyfikowanej przez Rzeczpospolita Polska umowy międzynarodowej lub ustawy wykonującej akt prawa stanowionego przez organizację międzynarodową, której Rzeczpospolita Polska jest członkiem, pod warunkiem że czyn objęty wnioskiem o ekstradycję: (1) został popełniony poza terytorium Rzeczypospolitej Polskiej, oraz (2) stanowił przestępstwo według prawa Rzeczypospolitej Polskiej lub stanowiłby przestępstwo według prawa Rzeczypospolitej Polskiej w razie popetnienia na terytorium Rzeczypospolitej Polskiej, zarówno w czasie jego popetnienia, jak i w chwili złożenia wniosku.

\section{Podsumowanie}

Projekt ustawy ma na celu uregulowanie niektórych spraw na wypadek wystąpienia Zjednoczonego Królestwa Wielkiej Brytanii i Irlandii Północnej z Unii Europejskiej i Europejskiej Wspólnoty Energii Atomowej na podstawie umowy, o której mowa w art. 50 ust. 2 TUE. Przepisy projektowanej ustawy znajdą zastosowanie wyłącznie w sytuacji, gdy wystąpienie Zjednoczonego Królestwa z Unii Europejskiej nastąpi na podstawie umowy, o której mowa w art. 50 ust. 2 TUE.

Do dnia sporządzenia niniejszej opinii w Zjednoczonym Królestwie nie zakończyły się wewnętrzne procedury mające na celu zatwierdzenie umowy. Wobec powyższego nie można jednoznacznie przewidzieć, czy i kiedy umowa wejdzie w życie. 